九州大学学術情報リポジトリ

Kyushu University Institutional Repository

\title{
CRYSTAL CONTACT/FREE CONFORMATION OF AN INTRINSICALLY FLEXIBLE LOOP IN PROTEIN CRYSTAL: TIM21 AS THE CASE STUDY
}

斯琴巴拉

http://hdl. hand le. net/2324/4060009

出版情報: Kyushu University，2019，博士（システム生命科学），課程博士 バージョン：

権利関係 : 
氏 名：斯琴巴拉

論文名 : CRYSTAL CONTACT-FREE CONFORMATION OF AN INTRINSICALLY FLEXIBLE LOOP IN PROTEIN CRYSTAL: TIM21 AS THE CASE STUDY

(蛋白質分子中の柔軟なループのコンホメーションを結晶コンタクト フリー空間を利用して解析：Tim 21 を例として）

区 分 : 甲

論文内容の要旨

In protein crystal, flexible loops are frequently deformed by crystal contacts, whereas in solution NMR, the large motions of flexible loops result in poor convergence. The correct three-dimensional structural information of protein molecules is vital for understanding their biochemical functions. We need an experimental technique to characterize the structural and dynamic properties of intrinsically flexible loops of protein molecules.

We designed an intended crystal contact-free space (CCFS) in protein crystals, and arranged the flexible loop of interest in the CCFS. The yeast Tim 21 protein was chosen as the model protein, because one of the loops (loop 2) is distorted by crystal contacts in the conventional crystal.

The intermembrane space fragment of the yeast Tim21 protein was fused to the MBP protein by a rigid $\alpha$ -helical linker. The space created between the two proteins was used as the CCFS. The linker length provides an adjustable freedom to arrange loop 2 in the CCFS. We determined the crystal structures of three MBP-Tim21 fusion proteins with different designs. Because the conformation of loop 2 in the best CCFS of three fusion proteins was distinct from it in the NMR structure reported in 2014, we re-determined the NMR structure of the yeast Tim21 and conducted MD simulations for comparison. Multidimensional scaling was used to visualize the structural similarity of loop 2. We found that the crystal contact-free conformation of loop 2 is located close to the centers of the loop 2 conformations' ensembles in the new NMR and MD structures, respectively. We conclude that loop 2 of the yeast Tim21 in the best CCFS adopts a representative conformation in solution.

General significance of this article: No single powerful technique is available for the characterization of flexible structures in protein molecules. NMR analyses and MD simulations provide useful, but incomplete information. CCFS crystallography offers a third route to this goal. 
